\title{
Pengaruh Kepemimpinan Terhadap Kinerja Pegawai di UPTD. Puskesmas Kentara Dinas Kesehatan Kabupaten Dairi
}

\author{
${ }^{1}$ Bunga Rosario Hutabarat, ${ }^{2}$ Evy Aryanti, ${ }^{3}$ Heriati, ${ }^{4}$ Khairil Efendi \\ ${ }^{1-4}$ Program Studi Magister Manajemen, Fakultas Ekonomi, Universitas Islam Sumatera Utara
}

\author{
Article history \\ Received: 2 Jan 2021 \\ Revised: 22 Feb 2021 \\ Accepted: 02 Mar 2021 \\ *Corresponding Author: \\ Bunga Rosario Hutabarat, \\ Program Studi Magister \\ Manajemen, Fakultas \\ Ekonomi, Universitas Islam \\ Sumatera Utara \\ Email: \\ bungarosarihtb@gmail.co \\ $\underline{\mathrm{m}}$
}

\begin{abstract}
Abstrak: Penting untuk mengungkapkan bagaimana pengaruh kepemimpinan terhadap kinerja pegawai di UPTD. Puskesmas Kentara Dinas Kesehatan Kabupaten Dairi, dan tujuan penelitian ini adalah untuk mengetahui dan menganalisis pengaruh kepemimpinan di UPTD Puskesmas Kentara Dinas Kesehatan Kabupaten Dairi. Penelitian ini merupakan penelitian deskriptif kuantitatif. Teknik pengumpulan data dilakukan melalui wawancara, daftar pertanyaan (Quisioner) dan studi dokumentasi. Sampel dalam penelitian ini sebanyak 39 orang. Hasil penelitian ini menunjukan bahwa Dari hasil perhitungan diperoleh nilai thitung $>\mathrm{t}$ tabel $(5.354>1.687)$ dan nilai signifikasi $0,000<0,05$, sehingga $\mathrm{H} 0$ ditolak dan Ha diterima. Artinya ada pengaruh variabel kepemimpinan terhadap kinerja pegawai di UPTD. Puskesmas Kentara. Besarnya pengaruh kepemimpinan terhadap kinerja pegawai sebesar 0.537 atau $53.70 \%$. Maka variabel kepemimpinan berpengaruh positif dan signifikan terhadap kinerja pegawai UPTD. Puskesmas Kentara

Kata Kunci : Kepemimpinan, Kinerja pegawai, Sumber Daya Manusia
\end{abstract}

\section{PENDAHULUAN}

Pembangunan suatu bangsa memerlukan modal utama yaitu sumber daya manusia. Sudah sejak lama dimaklumi bahwa sumber daya manusia (SDM) merupakan faktor pertama dan terutama dalam memajukan kesejahteraan suatu bangsa. Pengalaman banyak negara sudah membuktikan kebenaran pendapat tersebut. Berbagai negara di dunia yang meskipun tidak memiliki sumber daya alam, akan tetapi jika mempunyai sumber daya manusia yang terdidik, terampil, berdisiplin, tekun, mau bekerja keras dan setia kepada cita-cita perjuangan bangsanya, ternyata berhasil meraih kemajuan yang sangat besar bahkan kadang-kadang membuat negara lain kagum terhadapnya. Menurut Mangkunegara (2013:2) manajemen sumber daya manusia merupakan suatu perencanaan, pengorganisasian, pengkoordinasian, pelaksanaan dan pengawasan terhadap pengadaan, pengembangan, pemberian balas jasa, pengintegrasian, pemeliharaan, dan pemisahan tenaga kerja dalam rangka mencapai tujuan organisasi.

Di Indonesia, aspek sumber daya manusia mendapatkan perhatian yang cukup besar dalam strategi pembangunan. Hal itu tentu saja tidak terlepas dari akibat terjadinya pergeseran orientasi dan strategi pembangunan nasional. Menurut Ma'arif (2013:112) "dalam era globalisasi dan sejalan pula dengan diberlakukannya Undang-Undang yang berlaku". Undang-Undang Nomor 25 Tahun 2004 tentang Sistem Perencanaan Pembangunan Nasional dan Undang-Undang Nomor 32 Tahun 2004 tentang Pemerintahan Daerah, penyelenggaraan pemerintahan yang baik (good governance) menuntut adanya keterbukaan, demokratisasi, partisipasi dan pelayanan prima kepada masyarakat, sebagai akibat semakin tingginya kesadaran masyarakat bahwa mereka mempunyai hak untuk memperoleh pelayanan yang semakin baik dari Pemerintah. Menurut Wibowo (2012:7) bahwa "kinerja adalah tentang 
melakukan pekerjaan dan hasil yang dicapai dari pekerjaan tersebut, kinerja adalah tentang apa yang dikerjakan dan bagaimana cara mengerjakannya".

Dalam organisasi pemerintahan, tuntutan akan pelayanan menjadi semakin besar bersamaan dengan perkembangan masyarakat. Aparatur pemerintah dalam lembaga birokrasi dituntut untuk mampu mengaktualisasikan dirinya sebagai sumber daya manusia yang berkualitas. Hal ini sangat diperlukan mengingat aparatur pemerintah adalah abdi negara dan abdi masyarakat yang diharapkan dapat memberikan pelayanan yang prima kepada masyarakat. Peningkatan pelayanan dan tuntutan masyarakat merupakan kondisi yang tidak dapat dielakkan. Pemimpin akan memberikan pengaruh yang berarti terhadap kinerja karyawan karena pemimpin yang merencanakan, menginformasikan, membuat, dan mengevaluasi setiap keputusan yang harus dilaksanakan dalam instansi tersebut. Faktor faktor yang berhubungan dengan sikap, gaya dan perilaku kepemimpinan sangat berpengaruh terhadap kinerja karyawan.

Setiap Pegawai akan memiliki tingkat kepuasan yang berbeda - beda sesuai dengan sistem penilaian yang berlaku. Kepuasan kerja dapat mengarahkan pegawai untuk meningkatkan kinerja menjadi lebih baik dan ketidakpuasan akan menurunkan kinerja Pegawai. Pencapaian kinerja yang baik dapat diperoleh melalui kekuatan sumber daya manusiannya.

Apakah kepemimpinan, mempunyai pengaruh yang signifikan terhadap kinerja pegawai, dan faktor manakah yang mempunyai pengaruh dominan terhadap kinerja pegawai. Konsep Gaya Kepemimpinan Thoha (2010: 76) menyatakan bahwa gaya kepemimpinan adalah suatu pola perilaku yang konsisten yang kita tunjukkan dan diketahui oleh pihak lain ketika kita berusaha memengaruhi kegiatan-kegiatan orang lain. Dari hasil jawaban atas pertanyaan tersebut, diharapkan pimpinan instansi dapat membuat program yang tepat untuk meningkatkan kinerja pegawai, karena peningkatan kinerja pegawai menjadi harapan baik bagi pimpinan instansi seperti Kepala UPTD. Puskesmas Kentara Dinas Kesehatan Kabupaten Dairi yang mempunyai posisi atau peran yang sangat penting dan strategis dalam rangka melakukan peran pemerintah daerah guna meningkatkan pelayanan kesehatan masyarakat, Berdasarkan uraian yang telah kami kemukakan di atas, penulis tertarik untuk mengadakan penelitian dengan judul: "Pengaruh Kepemimpinan, Terhadap Kinerja Pegawai di UPTD. Puskesmas Kentara Dinas Kesehatan Kabupaten Dairi “.

\section{METODE PENELITIAN}

Lokasi Penelitian dilakukan di UPTD. Puskesmas Kentara Dinas Kesehatan Kabupaten Dairi yang beralamat di jalan Sidikalang Parongil Desa Kentara Kecamatan Lae Parira Kabupaten Dairi. Objek penelitian ini adalah Pegawai Puskesmas Kentara, Dinas Kesehatan Kabupaten Dairi, dimana penelitian ini merupakan penelitian sebab akibat yaitu penelitian yang tujuannya untuk menganalisa pengaruh tiga variabel bebas (independen) terhadap satu variabel terikat (dependen). Adapun variabel bebas yang dimakud dalam Penelitian ini adalah kepemimpinan sebagai Variabel X, dan kinerja Pegawai sebagai Variabel Y yang merupakan variabel terikat.

\section{HASIL DAN PEMBAHASAN}




\section{Identitas responden}

1. Identitas responden berdasarkan usia

Tabel 1. Identitas responden berdasarkan Usia

\begin{tabular}{cccc}
\hline No & Usia & Jumlah & Persentase \\
\hline 1 & $26-30$ & 1 Orang & $2,6 \%$ \\
2 & $31-35$ & 12 Orang & $30,8 \%$ \\
3 & $36-40$ & 10 Orang & $25,6 \%$ \\
3 & $>40$ & 16 Orang & $41 \%$ \\
& T o t a l & 39 & 100
\end{tabular}

Sumber : UPTD. Puskesmas Kentara

Dari Tabel 1 di atas dapat dijelaskan bahwa responden usia 26 - 30 tahun berjumlah 1 orang $(2,6 \%)$, usia $31-35$ berjumlah 12 orang (30,8\%), usia 36 - 40 tahun berjumlah 10 orang $(25.6 \%)$ dan diatas $>41$ berjumlah 16 orang $(41 \%)$.

2. Identitas responden berdasarkan jenis kelamin

Tabel 2. Identitas responden berdasarkan jenis kelamin

\begin{tabular}{cccc}
\hline No & Jenis Kelamin & Jumlah & Persentase \\
\hline 1 & Laki laki & 3 Orang & $7,7 \%$ \\
2 & Perempuan & 36 Orang & $92,3 \%$ \\
T o t a l & 39 & 100
\end{tabular}

Sumber : UPTD. Puskesmas Kentara

Dari Tabel 2 diatas dapat dijelaskan bahwa responden berjenis kelamin laki-laki adalah berjumlah 3 orang $(7,7 \%)$, perempuan berjumlah 39 orang $(92,3 \%)$.

3. Identitas responden berdasarkan jenjang Masa Kerja

Tabel 3. Identitas responden berdasarkan masa kerja

\begin{tabular}{clcr}
\hline No & \multicolumn{1}{c}{ Pendidikan } & Jumlah & Persentase \\
\hline 1 & 1-5 Tahun & 8 Orang & $20,5 \%$ \\
2 & 6-10 Tahun & 6 Orang & $15,5 \%$ \\
3 & 11 - 15 Tahun & 12 Orang & $30,7 \%$ \\
4 & $>$ 16 Tahun & 13 Orang & $33,3 \%$ \\
To t a l & & 39 & 100
\end{tabular}

Sumber : UPTD. Puskesmas Kentara

Dari Tabel 5.4. diatas dapat dijelaskan bahwa responden dengan masa kerja 1-5 tahun berjumlah 8 orang $(20,5 \%)$, masa kerja 6-10 tahun berjumlah 6 orang (15,5\%), masa kerja 11-15 tahun berjumlah 12 orang $(33,3 \%)$.

\section{Analisis Deskriptif}

Analisis deskriptif digunakan untuk mengetahui gambaran tentang variabel-variabel yang diteliti dengan berdasarkan pada distribusi frekuensi jawaban responden dan tanggapan atas pernyataan-pernyataan dalam kuesioner. Item-item pernyataan dalam variabel-variabel yang diteliti tersebut secara keseluruhan digambarkan dalam bentuk tabel deskripsi frekuensi. 
Dalam hal ini penulis melakukan dengan analisis deskriptif frekuensi, sehingga diketahui frekuensi, persen, dan nilai serta kategori lain.

\section{a. Analisis Deskriptif Variabel Kepemimpinan (X)}

Rekapitulasi distribusi frekuensi tanggapan responden terhadap item-item pernyataan variabel kepemimpinan adalah sebagai berikut :

Tabel 4. Deskripsi tanggapan responden terhadap variabel kepemimpinan

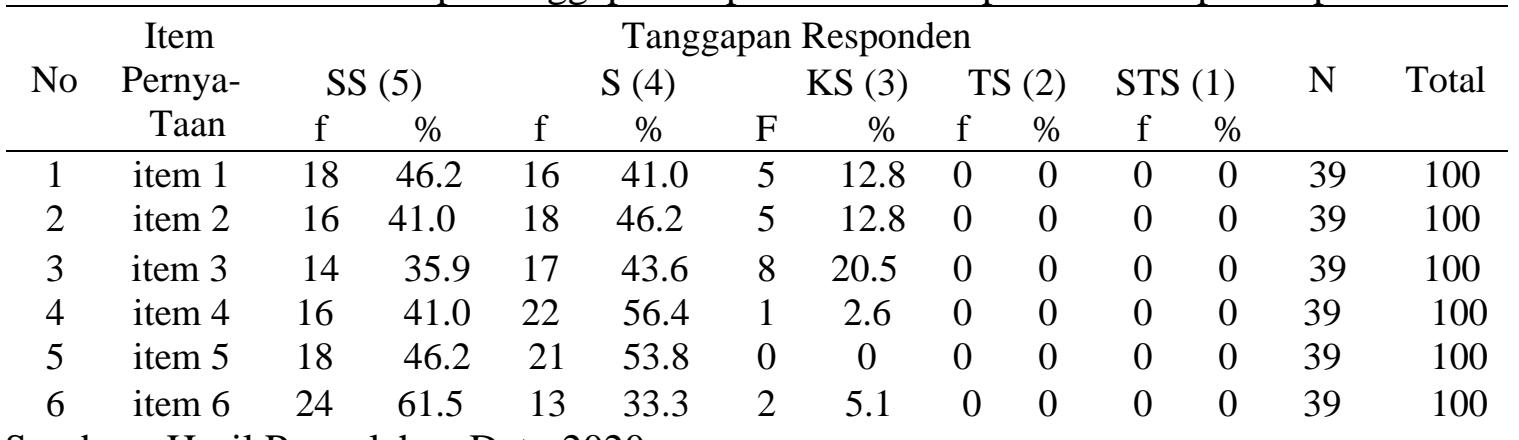

Sumber : Hasil Pengolahan Data-2020

Berdasarkan tabel 5.5 di atas dapat dideskripsikan tanggapan responden terhadap itemitem variabel kepemimpinan yaitu :

1) Tanggapan responden terhadap pernyataan (item 1) : UPTD. Puskesmas Kentara, sebagian besar responden menjawab sangat setuju yaitu 18 orang (46.2\%), setuju 16 orang $(41.0 \%)$ dan kurang setuju 5 orang (12.8\%).

2) Tanggapan responden terhadap pernyataan (item 2) : UPTD. Puskesmas Kentara, sebagian besar responden menjawab sangat setuju yaitu 16 orang (41.0\%), setuju 18 orang $(46.2 \%)$ dan kurang setuju 5 orang $(12.8 \%)$.

3) Tanggapan responden terhadap pernyataan (item 3) : UPTD. Puskesmas Kentara, sebagian besar responden menjawab sangat setuju yaitu 14 orang (35.9\%), setuju 17 orang $(43.6 \%)$ dan kurang setuju 8 orang $(20.5 \%)$.

4) Tanggapan responden terhadap pernyataan (item 4) : UPTD. Puskesmas Kentara, sebagian besar responden menjawab sangat setuju yaitu 16 orang (41.0\%), setuju 22 orang $(56.4 \%)$ dan tidak setuju 1 orang $(2.6 \%)$.

5) Tanggapan responden terhadap pernyataan (item 5) : UPTD. Puskesmas Kentara, sebagian besar responden menjawab sangat setuju yaitu 18 orang (46.2\%) dan setuju 21 orang $(53.8 \%)$.

6) Tanggapan responden terhadap pernyataan (item 6) : UPTD. Puskesmas Kentara, sebagian besar responden menjawab sangat setuju yaitu 24 orang (61.5\%), setuju 13 orang (33.3\%) dan kurang setuju 2 orang (5.1\%).

\section{b. Analisis Deskriptif Variabel Kinerja Pegawai (Y)}

Rekapitulasi distribusi frekuensi tanggapan responden terhadap item-item pernyataan variabel kinerja pegawai adalah sebagai berikut :

Tabel 5. Deskripsi Tanggapan Responden Terhadap Variabel Kinerja Pegawai

\begin{tabular}{|c|c|c|c|c|c|c|c|c|c|c|c|c|}
\hline \multirow{3}{*}{ No } & Item & \multicolumn{9}{|c|}{ Tanggapan Responden } & \multirow{3}{*}{$\mathrm{N}$} & \multirow{3}{*}{ Total } \\
\hline & Pernya- & & $S(5)$ & & S (4) & & & $\mathrm{TS}(2)$ & ST & & & \\
\hline & Taan & $\mathrm{f}$ & $\%$ & $\mathrm{f}$ & $\%$ & $\mathrm{f}$ & $\%$ & f $\%$ & $\mathrm{f}$ & $\%$ & & \\
\hline 1 & item 1 & 16 & 41.0 & 23 & 59.0 & 0 & 0 & 0 & 0 & 0 & 39 & 100 \\
\hline
\end{tabular}




$\begin{array}{rrrrrrrrrrrrrr}2 & \text { item 2 } & 28 & 71.8 & 11 & 28.2 & 0 & 0 & 0 & 0 & 0 & 0 & 39 & 100 \\ 3 & \text { item 3 } & 16 & 41.0 & 22 & 56.4 & 1 & 2.6 & 0 & 0 & 0 & 0 & 39 & 100 \\ 4 & \text { item 4 } & 18 & 46.2 & 18 & 46.2 & 3 & 7.7 & 0 & 0 & 0 & 0 & 39 & 100 \\ 5 & \text { item 5 } & 26 & 66.7 & 13 & 33.3 & 0 & 0 & 0 & 0 & 0 & 0 & 39 & 100 \\ 6 & \text { item 6 } & 25 & 64.1 & 14 & 35.9 & 0 & 0 & 0 & 0 & 0 & 0 & 39 & 100 \\ 7 & \text { item 7 } & 28 & 71.8 & 11 & 28.2 & 0 & 0 & 0 & 0 & 0 & 0 & 39 & 100\end{array}$

Sumber : Hasil Pengolahan Data-2020

Berdasarkan tabel 5 di atas dapat dideskripsikan tanggapan responden terhadap itemitem variabel kinerja :

1) Tanggapan responden terhadap pernyataan (item 1) : UPTD. Puskesmas Kentara, sebagian besar responden menjawab sangat setuju yaitu 16 orang $(41.0 \%)$ dan setuju 23 orang $(59.0 \%)$.

2) Tanggapan responden terhadap pernyataan (item 2) : UPTD. Puskesmas Kentara, sebagian besar responden menjawab sangat setuju yaitu 28 orang (71.80\%) dan setuju 11 orang $(28.2 \%)$.

3) Tanggapan responden terhadap pernyataan (item 3) : UPTD. Puskesmas Kentara, sebagian besar responden menjawab sangat setuju yaitu 16 orang $(41.0 \%)$, setuju 22 orang $(56.4 \%)$ dan kurang setuju 1 orang $(2.6 \%)$.

4) Tanggapan responden terhadap pernyataan (item 4) : UPTD. Puskesmas Kentara, sebagian besar responden menjawab sangat setuju yaitu 18 orang (46.2\%), setuju 18 orang $(46.2 \%)$ dan tidak setuju 3 orang $(7.7 \%)$.

5) Tanggapan responden terhadap pernyataan (item 5) : UPTD. Puskesmas Kentara, sebagian besar responden menjawab sangat setuju yaitu 26 orang $(66.7 \%)$ dan setuju 13 orang $(33.3 \%)$.

6) Tanggapan responden terhadap pernyataan (item 6) : UPTD. Puskesmas Kentara, sebagian besar responden menjawab sangat setuju yaitu 25 orang $(64.1 \%)$ dan setuju 14 orang $(35.9 \%)$.

7) Tanggapan responden terhadap pernyataan (item 7) : UPTD. Puskesmas Kentara, sebagian besar responden menjawab sangat setuju yaitu 28 orang $(71.8 \%)$ dan setuju 11 orang $(28.2 \%)$.

\section{Uji Validitas}

Uji validitas item adalah uji statistik yang digunakan guna menentukan seberapa valid suatu item pertanyaan mengukur variabel yang diteliti. Uji Reliabilitas item adalah uji statistik yang digunakan guna menentukan reliabilitas serangkaian item pertanyaan dalam kehandalannya mengukur suatu variabel. Pengukuran valid atau tidaknya kuesioner ditentukan oleh uji validitas. Kuesioner dikatakan valid jika data yang sesungguhnya terjadi pada objek dapat mengungkapkan dengan pasti apa yang akan diteliti (Sugiyono, 2013: 172).

\section{a. Hasil Uji Validitas Variabel Kepemimpinan (X).}

Tabel 6. Output Uji Validitas Variabel Kepemimpinan

$\begin{array}{ccc}\text { Angket } & \text { Signifikansi } & \text { Keterangan } \\ 1 & 0.012<0.05 & \text { Valid } \\ 2 & 0.002<0.05 & \text { Valid }\end{array}$




$\begin{array}{lll}3 & 0.000<0.05 & \text { Valid } \\ 4 & 0.000<0.05 & \text { Valid } \\ 5 & 0.000<0.05 & \text { Valid } \\ 6 & 0.000<0.05 & \text { Valid }\end{array}$

Sumber : Hasil pengolahan data-2020

Dari tabel di atas dapat dijelaskan bahwa nilai signifikansi butir-butir pertanyaan untuk variabel kepemimpinan keseluruhannya dinyatakan valid, karena nilai signifikansinya di bawah nilai $\alpha=0.05$.

\section{b. Hasil Uji Validitas Variabel Kinerja (Y).}

Tabel 7. Output Uji Validitas Variabel Kinerja

\begin{tabular}{ccc}
\hline Angket & Signifikansi & Keterangan \\
\hline 1 & $0.000<0.05$ & Valid \\
2 & $0.044<0.05$ & Valid \\
3 & $0.000<0.05$ & Valid \\
4 & $0.004<0.05$ & Valid \\
5 & $0.000<0.05$ & Valid \\
6 & $0.000<0.05$ & Valid \\
7 & $0.001<0.05$ & Valid
\end{tabular}

Sumber : Hasil pengolahan data-2020

Dari tabel di atas dapat dijelaskan bahwa nilai signifikansi butir-butir pertanyaan untuk variabel kinerja keseluruhannya dinyatakan valid, karena nilai signifikansinya di bawah nilai $\alpha=0.05$.

\section{Uji Reliabilitas}

Uji reliabilitas sebenarnya adalah alat untuk mengukur suatu kuesioner yang merupakan indikator dari variabel atau konstruk. Suatu kuesioner dikatakan reliabel atau handal jika jawaban responden terhadap pernyataan adalah konsisten atau stabil dari waktu ke waktu. SPSS yang memberikan fasilitas untuk mengukur reliabilitas dengan uji statistik Cronbach Alpha. Suatu konstruk atau variabel dikatakan reliable jika memberikan nilai Cronbach Alpha > 0,60. Dalam penelitian ini menggunakan one shot supaya lebih efisien dalam waktu penyelesaian penelitian.

\section{a. Hasil Uji Reliabilitas Variabel Kepemimpinan (X)}

Tabel 8. Output Uji Reliabilitas Variabel Kepemimpinan

Item-Total Statistics

\begin{tabular}{lrrrr}
\hline & $\begin{array}{c}\text { Scale Mean if } \\
\text { Item Deleted }\end{array}$ & $\begin{array}{c}\text { Scale Variance } \\
\text { if Item Deleted }\end{array}$ & $\begin{array}{c}\text { Corrected } \\
\text { Item-Total } \\
\text { Correlation }\end{array}$ & $\begin{array}{c}\text { Cronbach's } \\
\text { Alpha if Item } \\
\text { Deleted }\end{array}$ \\
\hline KP1 & 21.85 & 3.502 & .060 & .560 \\
KP2 & 21.90 & 3.252 & .173 & .499 \\
KP3 & 22.03 & 2.868 & .289 & .435 \\
KP4 & 21.79 & 3.220 & .326 & .423 \\
KP5 & 21.72 & 3.208 & .380 & .404 \\
KP6 & 21.62 & 2.980 & .394 & .383 \\
\hline \multicolumn{5}{c}{ Reliability Statistics } \\
\end{tabular}


Cronbach's Alpha $\quad$ N of Items

.499

\section{Sumber : Hasil Pengolahan Data-Tahun 2020}

Diketahui nilai $\mathrm{r}_{\text {tabel }}$ untuk uji dua sisi pada tingkat signifikan 5\% $(\alpha=0,05)$, dengan jumlah sample $\mathrm{N}=39$, maka derajat bebasnya adalah $\mathrm{N}-2=39-2=37$, dan diketahui nilai r-tabel $=0.325$. Dari hasil tabel di atas dapat terlihat bahwa nilai $\mathrm{r}_{\text {hitung }}$ pada kolom cronbach's alpha if item deleted semua lebih besar dari nilai $\mathrm{r}_{\text {tabel}}$, maka seluruh butir pernyataan untuk variabel kepemimpinan dinyatakan reliabel, begitu juga halnya pada tabel reliability statistics diketahui nilai Alpha Cronbach sebesar 0.499. Karena nilai Alpha Cronbach $>\mathrm{r}_{\text {tabel }}$ maka angket yang digunakan reliabel.

\section{b. Hasil Uji Reliabilitas Variabel Kinerja Pegawai (Y)}

Tabel 9. Output Uji Reliabilitas Variabel Kinerja

\section{Item-Total Statistics}

\begin{tabular}{ccccc}
\hline & $\begin{array}{c}\text { Scale Mean if } \\
\text { Item Deleted }\end{array}$ & $\begin{array}{c}\text { Scale Variance } \\
\text { if Item Deleted }\end{array}$ & $\begin{array}{c}\text { Corrected } \\
\text { Item-Total } \\
\text { Correlation }\end{array}$ & $\begin{array}{c}\text { Cronbach's } \\
\text { Alpha if Item } \\
\text { Deleted }\end{array}$ \\
\hline KJ1 & 27.51 & 2.783 & .500 & .520 \\
KJ2 & 27.21 & 3.536 & .069 & .651 \\
KJ3 & 27.54 & 2.676 & .501 & .514 \\
KJ4 & 27.54 & 2.729 & .350 & .574 \\
KJ5 & 27.26 & 3.248 & .224 & .610 \\
KJ6 & 27.28 & 2.997 & .374 & .564 \\
KJ7 & 27.21 & 3.167 & .300 & .587 \\
\multicolumn{5}{c}{ Reliability Statistics } \\
\hline \multicolumn{5}{c}{ Cronbach's Alpha } \\
\hline \multicolumn{5}{c}{ N of Items } \\
\hline
\end{tabular}

Sumber : Hasil Pengolahan Data-Tahun 2020

Diketahui nilai $\mathrm{r}_{\text {tabel }}$ untuk uji dua sisi pada tingkat signifikan $5 \%(\alpha=0,05)$, dengan jumlah sample $\mathrm{N}=39$, maka derajat bebasnya adalah $\mathrm{N}-2=39-2=37$, dan diketahui nilai r-tabel $=0.325$. Dari hasil tabel di atas dapat terlihat bahwa nilai $\mathrm{r}_{\text {hitung }}$ pada kolom cronbach's alpha if item deleted semua lebih besar dari nilai $r_{\text {tabel}}$, maka seluruh butir pernyataan untuk variabel kinerja dinyatakan reliabel, begitu juga halnya pada tabel reliability statistics diketahui nilai Alpha Cronbach sebesar 0.616. Karena nilai Alpha Cronbach $>\mathrm{r}_{\text {tabel }}$ maka angket yang digunakan reliabel.

\section{Analisis Regresi Linier Berganda.}

Analisis regresi linier berganda antara variabel kepemimpian, motivasi dan kepuasan kerja terhadap kinerja pegawai di UPTD. Puskesmas Kentara, maka dapat dilihat dari persamaan regresinya, dan dari output SPSS diperoleh data sebagai berikut: 
Tabel 10. Hasil uji statistik koefisien regresi pengaruh kepemimpinan, motivasi dan kepuasan kerja terhadap kinerja pegawai

Coefficients $^{\mathbf{a}}$

\begin{tabular}{|c|c|c|c|c|c|}
\hline \multirow[t]{2}{*}{ Model } & \multicolumn{2}{|c|}{ Unstandardized Coefficients } & \multirow{2}{*}{$\begin{array}{c}\text { Standardized } \\
\text { Coefficients } \\
\text { Beta }\end{array}$} & \multirow[t]{2}{*}{$\mathrm{t}$} & \multirow[t]{2}{*}{ Sig. } \\
\hline & B & Std. Error & & & \\
\hline (Constant) & 4.649 & 3.185 & & 1.460 & .153 \\
\hline KEPEMIMPINAN & .518 & .097 & .537 & 5.354 & .000 \\
\hline
\end{tabular}

a. Dependent Variable: KINERJA

Sumber: Hasil pengolahan data 2020

Berdasarkan Tabel di atas dapat dibuat persamaan regresi sebagai berikut

$$
\mathrm{Y}=4.649+0.518 \mathrm{X} 1+0.119 \mathrm{X} 2+0.412 \mathrm{X} 3
$$

Nilai kinerja pegawai di UPTD. Puskesmas Kentara, sebesar 4.649, yang mana nilai dari variabel kepemimpinan, motivasi dan kepuasan kerja diabaikan. Persamaan di atas menjelaskan bahwa koefisien regresi $\mathrm{X}_{1}$ (kepemimpinan) mempunyai nilai positif yaitu 0.518, hal ini menunjukkan bahwa variabel kepemimpinan mempunyai pengaruh positif terhadap kinerja pegawai di UPTD. Puskesmas Kentara. Hal bila kepemimpinan meningkat $1 \%$, maka kinerja pegawai akan bertambah 5.18\%. Koefisien regresi $\mathrm{X}_{2}$ (motivasi) juga mempunyai nilai positif yaitu 0.119 , hal ini menunjukkan bahwa variabel motivasi kerja mempunyai pengaruh positif terhadap kinerja pegawai di UPTD. Puskesmas Kentara. Hal bila motivasi meningkat $1 \%$, maka kinerja pegawai akan bertambah $1.19 \%$.

Koefisien regresi $\mathrm{X}_{3}$ (kepuasan kerja) juga mempunyai nilai positif yaitu 0.412 , hal ini menunjukkan bahwa variabel kepuasan kerja mempunyai pengaruh positif terhadap kinerja pegawai di UPTD. Puskesmas Kentara. Hal bila kepuasan kerja meningkat 1\%, maka kinerja pegawai akan bertambah $4.12 \%$.

\section{Pengaruh Kepemimpinan Terhadap Kinerja Pegawai di UPTD. Puskesmas Kentara}

Untuk mengetahui pengaruh kepemimpinan terhadap kinerja pegawai di UPTD. Puskesmas Kentara digunakan uji-t, sedangkan untuk melihat besarnya pengaruh digunakan angka Beta atau Standardized Coefficient.

Tabel 11. Coeficients ${ }^{\mathrm{a}}$ Pengaruh Kepemimpinan Terhadap Kinerja Pegawai

Coefficients $^{\mathbf{a}}$

\begin{tabular}{llrrrrr}
\hline Model & & \multicolumn{2}{c}{ Unstandardized Coefficients } & $\begin{array}{l}\text { Standardized } \\
\text { Coefficients } \\
\text { Beta }\end{array}$ & t & \multicolumn{2}{l}{ Sig. } \\
& & B & Std. Error & & \\
\hline 1 & (Constant) & 4.649 & 3.185 & & 1.460 & .153 \\
& KEPEMIMPINAN & .518 & .097 & .537 & 5.354 & .000
\end{tabular}

a. Dependent Variable: KINERJA

Sumber: Hasil pengolahan data 2020

Dari tabel di atas diperoleh nilai thitung sebesar 5.354. Penelitian ini menggunakan taraf signifikansi $(\alpha ; 0,05)$ dan Derajat Kebebasan (DK) dengan ketentuan DK $=\mathrm{n}-2$, atau $39-2$ 
$=37$. Dengan ketentuan tersebut, diperoleh nilai $t_{\text {tabel }}$ sebesar 1.687. Dengan kriteria hipotesis sebagai berikut :

Jika $\mathrm{t}_{\text {hitung }}>\mathrm{t}_{\text {tabel}}$, maka $\mathrm{H}_{0}$ ditolak dan $\mathrm{H}_{\mathrm{a}}$ diterima.

Jika $t_{\text {hitung }}<\mathrm{t}_{\text {tabel}}$, maka $\mathrm{H}_{0}$ diterima dan $\mathrm{H}_{\mathrm{a}}$ ditolak.

Dari hasil perhitungan diperoleh nilai $t_{\text {hitung }}>\mathrm{t}_{\text {tabel }}(5.354>1.687)$ dan nilai signifikasi $0,000<0,05$, sehingga $\mathrm{H}_{0}$ ditolak dan $\mathrm{H}_{\mathrm{a}}$ diterima. Artinya ada pengaruh variabel kepemimpinan terhadap kinerja pegawai di UPTD. Puskesmas Kentara. Besarnya pengaruh kepemimpinan terhadap kinerja pegawai sebesar 0.537atau 53.70\%.

\section{KESIMPULAN}

Nilai $t_{\text {hitung }}$ sebesar 5.354. Penelitian ini menggunakan taraf signifikansi $(\alpha ; 0,05)$ dan Derajat Kebebasan (DK) dengan ketentuan $\mathrm{DK}=\mathrm{n}-2$, atau $39-2=37$. Dengan ketentuan tersebut, diperoleh nilai tabel sebesar 1.687. Dengan kriteria hipotesis sebagai berikut :

Jika $t_{\text {hitung }}>\mathrm{t}_{\text {tabel}}$, maka $\mathrm{H}_{0}$ ditolak dan $\mathrm{H}_{\mathrm{a}}$ diterima.

Jika $t_{\text {hitung }}<\mathrm{t}_{\text {tabel}}$, maka $\mathrm{H}_{0}$ diterima dan $\mathrm{H}_{\mathrm{a}}$ ditolak.

Dari hasil perhitungan diperoleh nilai $t_{\text {hitung }}>t_{\text {tabel }}(5.354>1.687)$ dan nilai signifikasi $0,000<0,05$, sehingga $\mathrm{H}_{0}$ ditolak dan $\mathrm{H}_{\mathrm{a}}$ diterima. Artinya ada pengaruh variabel kepemimpinan terhadap kinerja pegawai di UPTD. Puskesmas Kentara. Besarnya pengaruh kepemimpinan terhadap kinerja pegawai sebesar 0.537atau 53.70\%. Maka variabel kepemimpinan berpengaruh positif dan signifikan terhadap kinerja pegawai UPTD. Puskesmas Kentara.

\section{DAFTAR PUSTAKA}

Ma'arif, Syamsul.2013. Posisi Strategis Birokrasi Dalam Transformasi Government ke Governance". Vol, 4. No, 2.

Mangkunegara. 2012. Manajemen Sumber Daya Manusia Perusahaan. Bandung: PT Remaja Rosdakarya.

Sugiyono.2013. Metode Penelitian Kuantitatif, Kualifikasi dan R\&D (Cetakan ke - 19), Bandung: Alfabeta CV.

Thoha, Miftah. 2012. Perilaku Organisasi Konsep Dasar dan Aplikasinya. Jakarta: Rajawali Pers.

Wibowo. 2012. Manajemen Kinerja. Jakarta: Raja Grafindo Persada. 